\title{
Pemberian Metode Progressive Muscle Relaxation Exercise Terhadap Kadar Hemoglobin (Hb) pada Remaja Putri
}

\section{Progressive Method of Progressive Relaxation of Training Muscle on Hemoglobin (Hb) Levels in Teenage Girl}

\author{
Binuko Amarseto, Lilik Ariyanti, Almas Awanis \\ bino.fisionesia@gmail.com \\ ${ }^{*}$ Program Studi D IV Fisioterapi, Sekolah Tinggi IImu Kesehatan Nasional, Sukoharjo, Indonesia
}

\begin{abstract}
Abstrak
Usia remaja merupakan usia peralihan dari masa kanak-kanak menuju masa dewasa. Pada usia remaja banyak perubahan yang terjadi, yaitu perubahan fisik karena bertambahnya massa otot, bertambahnya jaringan lemak dalam tubuh, juga terjadi perubahan hormonal. Remaja putri merupakan salah satu golongan yang rawan menderita anemia gizi besi karena mengalami menstruasi atau haid berkala yang mengeluarkan zat besi setiap bulan. Salah satu teknik untuk relaksasi adalah teknik PMR Jacobson. PMR menurut Jacobson adalah suatu keterampilan yang dipelajari dan digunakan untuk mengurangi atau menghilangkan ketegangan serta menimbulkan rasa nyaman tanpa tergantung pada subjek diluar dirinya. PMR ini digunakan untuk mengurangi rasa cemas, stres, atau ketegangan. Penelitian ini bertujuan untuk mengetahui pengaruh pemberian metode progressive muscle relaxation exercise terhadap kadar hemoglobin $(\mathrm{Hb})$ pada remaja putri. Penelitian ini merupakan penelitian studi pre-eksperimental menggunakan rancangan one grup pretest-posstest design. Pengumpulan data dilakukan dengan menggunakan kuisioner. Sampel penelitian yaitu remaja yang berjumlah 90 orang dengan menggunakan teknik simple random sampling. Analisis data menggunakan uji Wilcoxon test dengan taraf signifikansi 5\%. Hasil penelitian mendapatkan jumlah responden terbanyak adalah rombongan belajar 10 dengan jumlah 32 responden $(35,6 \%)$, jumlah responden rombongan belajar 11 berjumlah 30 responden $(33,3 \%)$ dan yang paling sedikit adalah rombongan belajar 12 dengan jumlah 28 responden $(31,1 \%)$. Hal ini menunjukkan bahwa ada pengaruh pemberian metode progressive muscle relaxation exercise terhadap kadar hemoglobin $(\mathrm{Hb})$ pada remaja putri $(p<0,05)$. Dari hasil penelitian ini dapat ditarik kesimpulan bahwa progressive muscle relaxation exercise dapat meningkatkan pengaruh kadar hemoglobin $(\mathrm{Hb})$ pada remaja putri. Aktivitas fisik tersebut dapat mempengaruhi kadar hemoglobin karena zat gizi yang dikonsumsi masuk ke dalam tubuh dibantu prosesnya untuk pembentukan hemoglobin $(\mathrm{Hb})$.
\end{abstract}

Kata kunci : progressive muscle relaxation exercise, remaja putri, Hemoglobin.

\begin{abstract}
Teenage age is a transition from childhood to adulthood. In adolescence many changes occur, namely physical changes due to increased muscle mass, increased fat tissue in the body, hormonal changes also occur. Adolescent girls are one of the groups who are prone to suffering from iron
\end{abstract}


nutritional anemia due to menstruation or periodic periods that release iron every month. One technique for relaxation is PMR Jacobson's technique. PMR according to Jacobson is a skill that is learned and used to reduce or eliminate tension and cause a sense of comfort without depending on the subject outside himself. PMR is used to reduce anxiety, stress, or tension. This study aims to determine the effect of the provision of progressive muscle relaxation exercise methods on hemoglobin $(\mathrm{Hb})$ levels in young women. This research is a preexperimental study using a one group pretest-posstest design. Data collection was carried out using a questionnaire. The research sample is adolescents, amounting to 90 people using simple random sampling technique. Data analysis using the Wilcoxon test with a significance level of 5\%. The results of the study found that the highest number of respondents was the 10 study groups with 32 respondents (35.6\%) while the number of respondents in the 11 study groups was 30 respondents (33.3\%) and the most 12 study groups consisted of 28 respondents $(31.1 \%)$. showed that there was an effect of the administration of progressive muscle relaxation exercise methods to hemoglobin $(\mathrm{Hb})$ levels in adolescent girls $(p<0.05)$. From the results of this study it can be concluded that progressive muscle relaxation exercise can increase the influence of hemoglobin $(\mathrm{Hb})$ levels in adolescent girls. Physical activity can affect hemoglobin levels because the nutrients consumed enter the body are assisted by the process for the formation of hemoglobin $(\mathrm{Hb})$.

Keywords: progressive muscle relaxation exercise, teenage girl, Hemoglobin.

\section{Pendahuluan}

Usia remaja merupakan usia peralihan dari masa kanak-kanak menuju masa dewasa. Pada usia remaja banyak perubahan yang terjadi, yaitu perubahan fisik karena bertambahnya massa otot, bertambahnya jaringan lemak dalam tubuh, juga terjadi perubahan hormonal. Perubahanperubahan itu mempengaruhi kebutuhan gizi dan makanan yang dikonsumsi (Moehji, 2009). Masa remaja dimulai kira-kira usia 10-13 tahun dan berakhir 18-22 tahun (Santrock, 2005).

Remaja putri merupakan salah satu golongan yang rawan menderita anemia gizi besi karena mengalami menstruasi atau haid berkala yang mengeluarkan zat besi setiap bulan (Sayogo, 2006). Wirakusumah (1999) menjelaskan bahwa dengan adanya menstruasi tersebut, maka dibutuhkan lebih banyak zat besi untuk pembentukan hemoglobin, karena zat besi yang hilang dari tubuh saat menstruasi juga banyak. Oleh karena itu, apabila kebutuhan zat besi yang tinggi tidak dapat dipenuhi dan asupannya rendah, maka kemungkinan terjadinya anemia gizi besi cukup besar.

Faktor-faktor yang mempengaruhi kadar hemoglobin dan sel darah merah (eritrosit) pada seseorang adalah makanan, usia, jenis kelamin, aktivitas, merokok, dan penyakit yang menyertainya seperti leukemia, thalasemia, dan tuberkulosi. Makanan merupakan zat-zat gizi atau komponen gizi yang terdapat dalam makanan yang dimakan digunakan untuk menyusun terbentuknya hemoglobin yaitu Fe (zat besi) dan protein. Jenis kelamin perempuan lebih mudah mengalami penurunan dari pada laki-laki, terutama pada saat menstruasi (Curtale et al., 2000) dalam Juanda (2013).

Hemoglobin sendiri adalah protein yang berada dalam sel darah merah. Terjadinya perubahan kadar hemoglobin di dalam darah dapat menandakan terjadinya gangguan kesehatan, terutama yang menyangkut darah. Fungsi hemoglobin yaitu membawa oksigen ke seluruh tubuh, tepatnya untuk organ dan jaringan tubuh. Kandungan oksigen yang terikat dengan hemoglobin pada sel darah yang membuat darah menjadi berwarna merah. Ukuran kadar hemoglobin tergantung usia dan jenis kelamin. Pada wanita dewasa di atas usia 18 tahun, kadar hemoglobin normal yaitu 12 sampai $15 \mathrm{~g} / \mathrm{dl}$. Kemudian, untuk pria dewasa diatas usia 18 tahun, kadar hemoglobin normal yaitu 13 sampai $17 \mathrm{~g} / \mathrm{dl}$ (Noya, 2017).

Salah satu upaya untuk menurunkan stress adalah dengan memberikan latihan 
Progressive Muscle Relaxation Exercise adalah bagaimana melemaskan otot-otot melalui dua proses langkah. Pertama, secara sistematis menegangkan kelompok otot tertentu otot tertentu di tubuh, misalnya seperti leher dan bahu. Latihan ini akan membantu menurunkan ketegangan secara keseluruhan dan tingkat stres, dan membantu rileks ketika merasa cemas. Ini juga dapat membantu mengurangi masalah fisik seperti sakit perut dan sakit kepala, serta meningkatkan tidur.

Penelitian dari Susanti dkk (2016) menunjukkan bahwa latihan relaksasi otot progresif bermanfaat menimbulkan respon tenang, nyaman, dan rileks dalam penelitiannya. Terapi yang bisa dilakukan untuk meningkatkan kualitas tidur dapat berupa nonfarmokologis yang dapat dilakukan dengan menggunakan relaksasi, sugesti, imajinasi, aromaterapi, terapi music, akupresure, dan terapi tertawa (Niet, Tiemens, Kloos, \& Hutschemaekers, 2009).

Berdasarkan uraian di atas maka rumusan masalah peneliti ini adalah bagaimana pengaruh pemberian metode Progressive Muscle Relaxation Exercise terhadap kadar Hemoglobin $(\mathrm{Hb})$ pada remaja putri.

\section{Metode}

Penelitian ini merupakan penelitian studi pre-eksperimental menggunakan rancangan one grup pretest-posstest design. Pengumpulan daa dilakukan dengan menggunakan alat pengukur Hemoglobin kepada sampel penelitian yang berjumlah 90 orang remaja putri. Analisis data menggunakan uji Wilcoxon test dengan taraf signifikansi 5\%. Variabel terikat dalam penelitian ini adalah kadar hemoglobin $(\mathrm{Hb})$ sedangkan variabel bebas dalam penelitian ini adalah progressive muscle relaxation exercise.

\section{Subjek penelitian}

Penelitian ini dilaksanakan pada bulan Mei 2019 dengan sampel penelitian berdasarkan rumus perhitungan mendapatkan sampel dengan jumlah 90 orang responden. Sampel dalam penelitian ini adalah siswa sekolah di Klaten.

\section{Instrumen Penelitian}

Form pengambilan data, digunakan untuk mengumpulkan data-data yang diambil dari hasil pemeriksaan kadar Hemoglobin pada sampel baik untuk nilai pre dan untuk nilai post. Selain itu juga diberikan quisioner untuk pengambilan data karakteristik responden.

\section{Jalannya Penelitian}

Peneliti mengambil sampel penelitian berdasarkan rumus yang dipakai kemudian melakukan pengambilan nilai pre hemoglobin, kemudian memberikan latihan Progressive Muscle Relaxation Exercise sesuai dosis yang ditetapkan dalam penelitian setelah itu diambil nilai post hemoglobin. Setelah itu kemudian data-data yang diperoleh dianalisa untuk mendapatkan hasil statistiknya.

\section{Analisa Data}

Mengalisis pengaruh pemberian metode Progressive Muscle Relaxation Exercise terhadap kadar Hemoglobin $(\mathrm{Hb})$ pada remaja putri menggunakan uji analisis komparatif Wilcoxon test.

\section{Hasil Dan Pembahasan}

Hasil penelitian ini karakteristik responden dalam penelitian ini berdasarkan jumlah rombongan belajar, rombongan belajar 10 dengan jumlah 32 responden $(35,6 \%)$ sedangkan jumlah responden rombongan belajar 11 berjumlah 30 responden $(33,3 \%)$ dan yang paling rombongan belajar 12 berjumlah 28 responden $(31,1 \%)$.

Berdasarkan distribusi nilai $\mathrm{Hb}$ Pre memiliki nilai minimum 12 , nilai maksimum 15 , nilai mean 13.48 , nilai median 13 dan nilai St.Deviasi 0.622 , sedangkan untuk kelompok post memiliki distribusi nilai minimum 13 , nilai maksimum 16, nilai mean 14.46, nilai median 14.50 dan nilai St.Deviasi 0.69.

Tabel 1. Hubungan antara pengetahuan kesehatan reproduksi dengan kecemasan.

\begin{tabular}{ccc}
\hline & Jumlah Sampel & Sig \\
\hline PMR & 45 & .001 \\
\hline
\end{tabular}

Berdasarkan tabel I. mendapatkan hasil analisa data bahwa jumlah sampel dalam penelitian ini adalah 90 responden, uji analisa data menggunakan uji Wilcoxon test mendapatkan hasil nilai signifikansi .001 nilai tersebut $<0,05$ yang berarti bahwa terdapat pengaruh pemberian metode progressive muscle relaxation exercise terhadap kadar hemoglobin $(\mathrm{Hb})$ pada remaja putri 


\section{Kesimpulan}

Aktivitas fisik adalah setiap gerakan tubuh yang meningkatkan pengeluaran tenaga, energi dan pembakaran kalori (Faizati. 2002). Aktivitas fisik dianjurkan minimal 30 menit, lebih lama akan lebih baik. Aktivitas fisik dapat dilakukan dimana saja, dengan memperhatikan lingkungan yang aman dan nyaman, bebas polusi, tidak menimbulkan cedera, misalnya : dirumah, sekolah, tempat kerja, dan tempattempat umum dengan sarana olahraga, lapangan, taman, tempat rekreasi. Aktivitas fisik dapat dimulai sejak usia muda hingga usia lanjut dan dapat dilakukan setiap hari.

Berkurangnya O2 yang ada dalam jaringan tubuh maka proses metabolisme juga akan terganggu dan tidak optimal. Sehingga kebutuhan akan energy untuk melakukan kegiatan fisik juga akan berkurang. Dengan berkurangnnya energi maka kegiatan fisik akan mengalami gangguan. Untuk itu gangguan kegiatan fisik inilah yang menjadi indikator status Kebugaran Jasmaninya kurang.

Progressive muscle relaxation dapat mempengaruhi tidur karena saat melakukan PMR akan memunculkan respon relaksasi (Trophotropic) yang menstimulasi semua fungsi dimana kerjanya berlawanan dengan system saraf simpatis sehingga tercapai keadaan rileks dan tenang. Perasaan rileks akan menghasilkan Corticotropin Releasing Factor (CRF) sehingga meningkatkan produksi beberapa hormon, seperti $\beta$-Endorphin, Enkefalin dan Serotonin (Ramdhani, 2008). Secara Fisiologis, terpenuhinya kebutuhan tidur terjadi karena penurunan aktifitas Reticular Activating System (RAS) dan noreepineprine sebagai akibat penurunan aktivitas sistem batang otak, sebagai akibat dari penurunan aktivitas Reticullar Activating System (RAS) dan peningkatan aktivitas batang otak akan menimbulkan sensasi nyaman sehingga merangsang timbulnya kantuk. (Feldman, Greeson, \& Senville, 2010).

\section{Daftar Pustaka}

Curtale F, Pezzotti P, Sharbini A.L, Maadat H.A, Ingrosso P, et al. 2000. Knowledege, Perceptions, and Behaviour of Mothers towards Intestinal Helminths in Upper Egypt: Implications for Control. Health Policy and Planning. 13(4): 423-432.

Faizati K. 2002. Panduan Kesehatan Olahraga. Jakarta : PPKORI.

Feldman, G., Greeson, J., \& Senville, J. (2010). Differential effect of mindful breathing, progressive muscle relaxation, and loving-kindness meditation on decentering and negative reactions to repetitive thoughts. Behavior Research and Therapy, 48

Juanda, Bambang., 2013. Metodologi Penelitian Ekonomi dan Bisnis. IPB Press. Bogor.

Moehji, S. 2009. Imu Gizi 2. Penerbit Papas Sinar Sinarti. Jakarta: 63, 66.

Niet, G. J. De, Tiemens, B. G., Kloos, M. W., \& Hutschemaekers, G. J. M. (2009). Review of systematic reviews about the efficacy of non-pharmacological interventions to improve sleep quality. International Journal Evidence Based Healthcare, 7, 233-242.

Nova, Allert Benedicto. 2017. Memahami Fungsi Hemoglobin dan Kadar Normalnya Dalam Tubuh. Alodokter.

Santrock, J.W. 2005. Adolescence, Perkembangan Remaja. Jakarta: Erlangga.

Sayogo, S. 2006. Giri dan Pertumbuban Remaja. Fakultas Kedokteran Fakultas Indonesia. Jakarta.

Susanti, H. 2016. Perbandingan Metode Somogyi-Nelson Dan Anthrone-Sulfat Pada Penetapan Kadar Gula Pereduksi Dalam Umbi Cilembu (Ipomea Batatas L.). J. Farmasi Sains Dan Komunitas, 13(2): 81-89.

Wirakusumah E. 2001. Cara Aman dan Efektif Menurunkan Berat Badan. Gramedia Pustaka Utama. Jakarta 